\title{
허리둘레-신장비와 관상동맥석회화
}

김정아, 강성구*, 송상욱, 신보라, 최연경

가톨릭대학교 의과대학 성빈센트병원 가정의학교실

\section{Waist Circumference-to-Height Ratio and Coronary Artery Calcification}

\author{
Jeong-ah Kim, Sung-Goo Kang*, Sang-Wook Song, Bora Shin, Yeon-kyung Choi \\ Department of Family Medicine, St. Vincent's Hospital, College of Medicine, The Catholic University of Korea, Suwon, Korea
}

Background: Many studies have demonstrated that the waist-to-height ratio (WHtR) is more correlated with coronary artery disease (CAD) than the body mass index (BMI). Coronary artery calcification (CAC) is an independent risk factor of atherosclerotic heart disease. However, the association between the WHtR and the coronary artery calcification score (CACS) still needs to be studied. The purpose of this study was to investigate the relationship between WHtR and CACS in healthy adults.

Methods: A total of 1,111 adults without a history of cardiovascular disease who visited the Health Promotion center at the University Hospital were included in this study. All subjects hadtheir CACS measured via multi-detector computed tomography (MDCT).

Results: Participants with a CACS $>0$ had a greater WHtR than those with a CACS of $0(0.535 \pm 0.006$ vs $0.517 \pm 0.005, P<0.001)$. After adjusting for risk factors that affect CAC, WHtR was an independent predictor of CAC (odds ratio: 1.04, $P=0.019,95 \% \mathrm{CI}: 1.01-1.07$ ). Male sex and systolic blood pressure are associated with 2.53 - and 1.02-fold increases in CAC, respectively $(P<0.001,95 \% \mathrm{CI}: 1.53-4.19 ; P=0.007,95 \%$ CI: 1.01-1.04).

Conclusion: In this study of adults without heart disease, WHtR was an independent predictor of CAC. These results suggest that WHtR may be a useful marker of CAD.

Key words: Waist-to-height ratio, Coronary artery calcification, Coronary heart disease

\section{서 론}

비만 관련 질병은 서구뿐 아니라 한국을 포함한 아시아 국가에서 도 심각한 수준으로 증가하고 있다. 아시아-태평양 코호트연구에 따 르면 14 개국 아시아-태평양 국가의 관상동맥질환 사망률의 0.8-9.2\% 가 과체중 및 비만과 관련이 있었다. ${ }^{1}$

비만은 고혈압, 당뇨병, 고지혈증의 위험인자로 알려져 있으며, 특히 복부 비만은 저고밀도지단백 콜레스테롤(low high-density lipoprotein cholesterol, 저HDL-콜레스테롤), 고중성지방(hypertriglyceride), 복부 비만, 고혈압, 고혈당으로 정의되는 대사증후군과 밀접한 관련이 있고, 이로 인한 심혈관계 질환 발생위험의 증가에 관여하는 것으로 알려져 있다. ${ }^{2}$ 또한 복부 비만은 관상동맥 석회화의 진행을 예 견하는 지표로서, 죽상동맥경화성 심혈관질환과 관련하여 중요한 임
상적 의미를 가지고 있다. ${ }^{3}$

그러나 비만을 평가하기 위해 가장 흔히 사용되고, 많은 연구가 이 루어진 체질량지수(body mass index, BMI)는 복부 비만을 제대로 반 영하지 못한다는 한계점이 있어, 복부 비만을 평가하기 위한 임상적 도구로서 허리둘레(waist circumference, WC), 허리둘레-엉덩이둘레 비(waist circumference-to-hip ratio, WHR), 허리둘레-신장비(waist circumference-to-height ratio, WHtR) 등이 제시되었고, 이 중 허리 둘레-신장비가 대사증후군 및 관상동맥질환과 관련이 높다는 최근 연구 결과들이 있었다. ${ }^{4-7}$ 국내에서도 허리둘레-신장비가 대사증후군 의 구성요소와 유의한 상관 있다는 결과가 보고된 바 있다. ${ }^{8}$

여러 연구들을 통해 허리둘레-신장비가 다양한 심혈관질환 위험 인자 및 대사증후군과 연관성이 있음이 밝혀졌으나, 허리둘레-신장 비와 관상동맥협착을 예견하는 지표가 되는 coronary artery calcifi-
Corresponding author Sung-Goo Kang (D) http://orcid.org/0000-0003-4627-291X Department of Family Medicine, St. Vincent's Hospital, College of medicine, The Catholic University of Korea, 93 Jungbu-daero, Paldal-gu, Suwon 16247, Korea Tel +82-31-249-8308 Fax+82-31-249-8253 E-mail hippo94@naver.com Received Nov. 3, 2015 Reviewed Nov. 24, 2015 Accepted Feb. 2, 2016
Copyright ( $@ 2016$ Korean Society for the Study of Obesity

() This is an Open Access article distributed under the terms of the Creative Commons Attribution Non-Commercial License (http://creativecommons.org/licenses/by-nc/4.0/) which permits unrestricted non-commercial use, distribution, and reproduction in any medium, provided the original work is properly cited. 
cation score (CACS)와의 관계에 대한 연구는 많지 않다.9-12 CACS는 점차 중요성이 높아지고 있는 심혈관계질환의 대리지표(surrogate marker)로서, CACS와 허리둘레-신장비의 연관성 연구는 심혈관질 환을 예측하기 위한 지표로서의 허리둘레-신장비의 유용성에 대한 중요한 근거가 될 수 있다. 따라서 본 연구는 건강한 성인에서 허리둘 레-신장비와 관상동맥 석회화의 관련성에 대해 알아보고자 하였다.

\section{방 법}

\section{1. 연구 대상}

2010년 1월 2일부터 2012년 12월 31일까지 경기도 소재 일개 대학병 원 건강검진센터에 내원하여 건강검진 및 Coronary artery MDCT를 시행한 20 세 이상의 성인 중 심혈관계질환의 과거력이 없는 1,111 명을 연구 대상으로 하였다.

본 연구는 동일 대학병원의 기관심의위원회(Institutional Review Board)의 승인을 받아 윤리 및 안전지침을 준수하면서 시행되었다 (VC15RISI0116).

\section{2. 연구 방법}

\section{1) 병력청취 및 신체계측}

검사 시작 전 미리 준비된 설문조사 양식에 따라 과거 병력, 약물 복용력, 흡연력, 음주력 등을 조사하였다. 체질량지수(BMI)는 검진 용 가운을 착용한 상태에서 InBody 3.0 model (Biospace, Korea)의 생체전기 임피던스법(bioelectrical impedence analysis, BIA)으로 측 정하였다. 허리둘레(WC)는 세계보건기구 권고방법에 따라 직립자세 로 숨을 편안히 내쉰 상태에서 늑골 하단부(lower border of rib cage) 와 장골능상부(top of iliac crest)의 중간 지점을 줄자를 이용하여 소 수점 한 자리까지 측정하였다. 혈압은 10 분 이상 안정상태를 취한 후 자동 혈압계로 측정하였다.

\section{2) 혈액검사}

8 시간 이상 공복 후 검사 당일 혈액을 채취하여 전자동 임상화학 분석기(Sysmex XE-2100, Japan; Hitachi 7600, Japan)의 flow cytometry 방법으로 공복혈당(serum glucose), 고밀도지단백 콜레스테롤 (high-density lipoprotein cholesterol), 중성지방(triglyceride, TG), 총 콜레스테롤(total cholesterol, TC), 저밀도지단백 콜레스테롤(lowdensity lipoprotein cholesterol, LDL-C) 등을 측정하였다.

\section{3) 관상동맥석회화 수치 측정}

CACS는 64-slice MDCT (Sensation 64, Siemens, Erlangen, Germany)를 이용하여 측정되었다. 검사 전 최소 6시간 동안 금식하였고,
심박동수가 65회/분 이상인 경우 베타차단제를 복용하게 하여 심박 수를 65회/분 이하로 유지하려 하였다.

조영제는 비이온성 조영제(Ultravist 370, Schering, Germany)를 60-70 mL 주입 후 Saline $40 \mathrm{~mL}$ 를 주입하였고, 심전도 동기화를 통해 영상을 얻은 후 재구성 프로그램(Wizard, Siemens, Erlangen, Germany)을 이용하여 관상동맥 석회화를 정량화하였다.

Agaston이 고안한 Agaston score의 기준에 따라 석회화 수치를 결 정하였고, 관상동맥은 우관상동맥(right coronary artery, RCA), 좌주 관상동맥(left main coronary artery, LMCA), 좌전하행관상동맥(left anterior descending artery, LAD), 좌회선관상동맥(left circumflex artery, LCA)으로 구분하여 정량화한 후 총 점수의 합을 구하였다.

\section{4) 대사증후군의 정의}

NCEP-ATP III에 제안된 기준에 따라 다음 각 항목 중 적어도 3 가 지 이상에 해당될 경우 대사증후군으로 정의하였다. 허리둘레는 대 한비만학회의 기준(남 $90 \mathrm{~cm}$, 여 $85 \mathrm{~cm}$ )을 사용하였다. ${ }^{13-15}$

(1) 복부 비만: 허리둘레 $\geq 90 \mathrm{~cm}$ (남), $\geq 85 \mathrm{~cm}$ (여)

(2) 중성지방: $\geq 150 \mathrm{mg} / \mathrm{dL}(1.69 \mathrm{mmol} / \mathrm{L})$ 또는 높은 중성지방에 대한 약물치료 중임

(3) 고밀도 지단백콜레스테롤: $<40 \mathrm{mg} / \mathrm{dL}(1.04 \mathrm{mmol} / \mathrm{L})$ (남), $<50 \mathrm{mg} / \mathrm{dL}$ (1.29 mmol/L) (여) 또는 낮은 고밀도 지단백콜레스테롤 에 대한 약물치료 중임

(4) 혈압: $\geq 130 / 85 \mathrm{mmHg}$ 또는 고혈압에 대한 약물치료 중임

(5) 혈당: $\geq 100 \mathrm{mg} / \mathrm{dL}(6.1 \mathrm{mmol} / \mathrm{L})$ 또는 혈당 상승에 대한 약물치 료중임

\section{5) 통계 분석}

연구를 위한 자료는 SPSS version 12.0 (SPSS Inc., Chicago, USA) 을 이용하여 분석하였으며, 통계적 유의 수준은 $P<0.05$ 인 경우로 하 였다. 연속 변수는 $t$-test를, 비연속 변수는 chi-squared test를 통해 분 석하였고, $\mathrm{CAC}$ 와 허리둘레-신장비 및 대사증후군 구성요소의 Odds ratio는 CAC에 영향을 미칠 수 있는 다른 요인들을 보정한 후 다중 로지스틱 회귀분석(Multiple logistic regression analysis)을 통하여 평 가하였다.

결 과

\section{1. 연구 대상자의 일반적 특성}

연구 대상자는 총 1,111 명으로 평균 연령은 $53.99 \pm 9.56$ 세였다. 여 성은 336 명 $(57.34 \pm 8.93$ 세), 남성은 775 명(52.54 \pm 9.47 세)이었다. 허리 둘레는 남성이 여성보다 길었으며 $(88.19 \pm 7.71 \mathrm{~cm}$ vs $82.76 \pm 9.56 \mathrm{~cm}$, 
$P<0.001)$, 체질량지수도 여성에 비해 남성이 더 높았다 $(25.11 \pm 2.94$ $\left.\mathrm{kg} / \mathrm{m}^{2} \mathrm{vs} 24.37 \pm 3.36 \mathrm{~kg} / \mathrm{m}^{2}, P<0.001\right)$. 그러나 허리둘레-신장비의 평 균은 남성 $0.518 \pm 0.04$, 여성 $0.531 \pm 0.07$ 로 여성이 더 높았다 $(P=$ 0.001) (Table 1).

\section{2. 관상동맥석회화와 대사인자들의 관계}

$\mathrm{CACS}=0$ 인 군에 비해 CACS $>0$ 인 군에서 허리둘레-신장비가 유 의하게 더 높았고 $(P<0.001)$, 허리둘레, 체질량지수, 수축기혈압, 공복 혈당, 총콜레스테롤, TG, LDL-C에 있어서도 유의하게 높은 결과를 보였다.

체지방량, 복부지방량은 $\mathrm{CACS}>0$ 인 군에서 높은 경향을 보였고, $\mathrm{HDL}$-콜레스테롤의 경우 두 군 간에 유의한 차이는 없었다.

또한 대사증후군이 없는 경우, CAC가 존재하는 경우가 $26.0 \%$ 였던 반면, 대사증후군이 동반된 경우에는 $40.7 \%$ 의 환자에서 CAC가 존 재하는 것으로 나타났다.

Table 1. Baseline characteristics of study subjects

\begin{tabular}{|c|c|c|c|c|}
\hline & $\begin{array}{c}\text { Total } \\
(\mathrm{N}=1,111)\end{array}$ & $\begin{array}{c}\text { Male } \\
(N=775)\end{array}$ & $\begin{array}{c}\text { Female } \\
(\mathrm{N}=336)\end{array}$ & $P$ value \\
\hline Age (yr) & $53.99 \pm 9.56$ & $52.54 \pm 9.47$ & $57.34 \pm 8.93$ & $<0.001$ \\
\hline Weight (kg) & $68.72 \pm 11.33$ & $72.9 \pm 9.92$ & $59.1 \pm 8.04$ & $<0.001$ \\
\hline Height (cm) & $165.92 \pm 8.59$ & $170.26 \pm 5.58$ & $155.96 \pm 5.41$ & $<0.001$ \\
\hline$W C(\mathrm{~cm})$ & $86.55 \pm 8.68$ & $88.19 \pm 7.71$ & $82.76 \pm 9.56$ & $<0.001$ \\
\hline WHtR & $0.522 \pm 0.05$ & $0.518 \pm 0.04$ & $0.531 \pm 0.07$ & 0.001 \\
\hline BMI $\left(\mathrm{kg} / \mathrm{m}^{2}\right)$ & $24.89 \pm 3.15$ & $25.11 \pm 2.94$ & $24.37 \pm 3.36$ & $<0.001$ \\
\hline Body fat $\left(\mathrm{cm}^{2}\right)$ & $27.67 \pm 6.84$ & $24.7 \pm 4.98$ & $34.47 \pm 5.55$ & $<0.001$ \\
\hline Abdominal fat $\left(\mathrm{cm}^{2}\right)$ & $0.96 \pm 0.84$ & $0.98 \pm 1.01$ & $0.91 \pm 0.06$ & 0.198 \\
\hline $\mathrm{SBP}(\mathrm{mmHg})$ & $127.87 \pm 14.10$ & $128.22 \pm 13.39$ & $127.06 \pm 15.62$ & 0.236 \\
\hline $\mathrm{DBP}(\mathrm{mmHg})$ & $77.71 \pm 9.91$ & $78.22 \pm 9.77$ & $76.52 \pm 10.15$ & 0.008 \\
\hline $\mathrm{FPG}(\mathrm{mg} / \mathrm{dL})$ & $99.8 \pm 22.36$ & $101.87 \pm 24.47$ & $95.03 \pm 15.51$ & $<0.001$ \\
\hline AST (IU/L) & $23.22 \pm 9.31$ & $24.15 \pm 10.07$ & $21.1 \pm 6.80$ & $<0.001$ \\
\hline ALT (IU/L) & $27.84 \pm 17.67$ & $30.7 \pm 18.94$ & $21.26 \pm 11.98$ & $<0.001$ \\
\hline $\mathrm{TC}(\mathrm{mg} / \mathrm{dL})$ & $204.32 \pm 37.22$ & $202.68 \pm 37.18$ & $208.07 \pm 37.11$ & 0.027 \\
\hline Triglyceride (mg/dL) & $141.88 \pm 88.15$ & $153.82 \pm 93.10$ & $114.44 \pm 68.15$ & $<0.001$ \\
\hline LDL-C (mg/dL) & $124.01 \pm 33.35$ & $122.73 \pm 33.32$ & $126.97 \pm 33.27$ & 0.051 \\
\hline $\mathrm{HDL}-\mathrm{C}(\mathrm{mg} / \mathrm{dL})$ & $45.95 \pm 11.27$ & $44.3 \pm 10.99$ & $49.74 \pm 11.02$ & $<0.001$ \\
\hline Metabolic syndrome & & & & 0.075 \\
\hline No & 723 & $491(63.4 \%)$ & $232(69.0 \%)$ & \\
\hline Yes & 388 & $284(36.6 \%)$ & $104(31.0 \%)$ & \\
\hline Smoking & & & & $<0.001$ \\
\hline Non-smoker & 446 & $127(28.5 \%)$ & $319(71.5 \%)$ & \\
\hline Ex-smoker & 335 & 330 (98.5\%) & $5(1.5 \%)$ & \\
\hline Current smoker & 330 & $318(96.4 \%)$ & $12(3.6 \%)$ & \\
\hline
\end{tabular}

Data are Mean $\pm \mathrm{SD}$ or $\mathrm{N}(\%) . P$ values were calculated by student $t$-test or chi-squared test.

WC, waist circumference; WHtR, waist circumference-to-height ratio; BMl, body mass index; SBP, systolic blood pressure; DBP, diastolic blood pressure; FPG, fasting plasma glucose; AST, aspartate transaminase; ALT, alanine transaminase; TC, total cholesterol; LDL-C, low-density lipoprotein cholesterol; HDL-C, high-density lipoprotein cholesterol.
한 번도 흡연을 하지 않은 비흡연자의 경우 CAC가 없는 환자의 비 율이 $74.2 \%$ 로, 과거 흡연자이거나(63.0\%), 현재 흡연자인 경우(67.6\%) 보다 높았다(Table 2).

\section{3. 다른 비만관련 지표(체질량지수, 허리둘레)와 CAC 유무와의 상관 관계}

$\mathrm{CAC}$ 유무와 체질량지수, 허리둘레, 허리둘레-신장비 각각의 상관 관계를 비교하였을 때, 허리둘레 신장비의 Coefficient $(\mathrm{r})$ 값은 0.161 $(P<0.001)$ 로 체질량지수 $(\mathrm{r}=0.109, P<0001)$, 허리둘레 $(\mathrm{r}=0.147$, $P<0.001)$ 보다 높았다(Table 3).

\section{4. 관상동맥석회화와 허리둘레-신장비}

다중 로지스틱 회귀분석(Multiple logistic regression analysis)을

Table 2. Comparison of each metabolic parameter according to CAC Scores

\begin{tabular}{|c|c|c|c|}
\hline & $\mathrm{CACS}=0(\mathrm{~N}=766)$ & CACS $>0(N=346)$ & $P$ value \\
\hline Age (yr) & $51.87 \pm 9.06$ & $58.68 \pm 8.96$ & $<0.001$ \\
\hline Gender & & & $<0.001$ \\
\hline Male & $509(65.7 \%)$ & $266(34.3 \%)$ & \\
\hline Female & $256(76.3 \%)$ & $80(23.7 \%)$ & \\
\hline Weight (kg) & $68.17 \pm 11.54$ & $69.93 \pm 10.76$ & 0.016 \\
\hline Height (cm) & $166.03 \pm 8.69$ & $165.69 \pm 8.37$ & 0.544 \\
\hline WC (cm) & $85.69 \pm 8.47$ & $88.45 \pm 8.84$ & $<0.001$ \\
\hline WHtR & $0.517 \pm 0.05$ & $0.535 \pm 0.006$ & $<0.001$ \\
\hline $\mathrm{BMI}\left(\mathrm{kg} / \mathrm{m}^{2}\right)$ & $24.66 \pm 3.15$ & $25.39 \pm 2.89$ & $<0.001$ \\
\hline Body fat $\left(\mathrm{cm}^{2}\right)$ & $27.59 \pm 6.97$ & $27.80 \pm 6.56$ & 0.641 \\
\hline Abd fat $\left(\mathrm{cm}^{2}\right)$ & $0.95 \pm 0.83$ & $0.98 \pm 0.87$ & 0.541 \\
\hline $\mathrm{SBP}(\mathrm{mmHg})$ & $126.44 \pm 14.08$ & $131.03 \pm 13.66$ & $<0.001$ \\
\hline $\mathrm{DBP}(\mathrm{mmHg})$ & $77.37 \pm 10.10$ & $78.46 \pm 9.45$ & 0.088 \\
\hline Fasting glucose (mg/dL) & $97.53 \pm 20.41$ & $104.82 \pm 25.49$ & $<0.001$ \\
\hline AST (IU/L) & $22.91 \pm 9.58$ & $23.92 \pm 8.64$ & 0.093 \\
\hline ALT (IU/L) & $27.80 \pm 18.61$ & $27.95 \pm 15.41$ & 0.896 \\
\hline $\mathrm{TC}(\mathrm{mg} / \mathrm{dL})$ & $202.21 \pm 35.91$ & $208.97 \pm 36.63$ & 0.007 \\
\hline Triglyceride (mg/dL) & $137.66 \pm 89.73$ & $151.24 \pm 83.90$ & 0.017 \\
\hline LDL-C (mg/dL) & $122.58 \pm 32.38$ & $127.19 \pm 35.22$ & 0.033 \\
\hline $\mathrm{HDL}-\mathrm{C}(\mathrm{mg} / \mathrm{dL})$ & $46.10 \pm 11.25$ & $45.60 \pm 11.33$ & 0.498 \\
\hline Metabolic syndrome & & & $<0.001$ \\
\hline No & $535(74.0 \%)$ & $188(26.0 \%)$ & \\
\hline Yes & $230(59.3 \%)$ & $158(40.7 \%)$ & \\
\hline Smoking & & & 0.003 \\
\hline Non-smoker & $331(74.2 \%)$ & $115(25.8 \%)$ & \\
\hline Ex-smoker & $211(63.0 \%)$ & $124(37.0 \%)$ & \\
\hline Current smoker & $223(67.6 \%)$ & $107(32.4 \%)$ & \\
\hline
\end{tabular}

Data are Mean $\pm \mathrm{SD}$ or $\mathrm{N}(\%)$. $P$ values were calculated by student $t$-test or chi-squared test.

CAC, coronary artery calcification; WC, waist circumference; WHtR, waist circumference-to-height ratio; BMI, body mass index; SBP, systolic blood pressure; DBP, diastolic blood pressure; FPG, fasting plasma glucose; AST, aspartate transaminase; ALT, alanine transaminase; TC, total cholesterol; LDL-C, low-density lipoprotein cholesterol; HDL-C, high-density lipoprotein cholesterol. 
Table 3. Correlation between each anthropometric obesity indicators and presence of CAC

\begin{tabular}{lcc}
\hline & Coefficients $(\mathrm{r})$ & $P$ value \\
\hline $\mathrm{BMI}\left(\mathrm{kg} / \mathrm{m}^{2}\right)$ & 0.109 & $<0.001$ \\
WC $(\mathrm{cm})$ & 0.147 & $<0.001$ \\
WHtR & 0.161 & $<0.001$
\end{tabular}

Coefficients ( $r$ ) and $P$ values were calculated by Pearson correlation model.

CAC, coronary artery calcification; WC, waist circumference; WHtR, waist circumference-to-height ratio.

통해 허리둘레-신장비 및 대사증후군의 각 구성요소들과 CAC 존재 와의 관계를 분석해 보았을 때, 허리둘레-신장비 $(\times 100)$ 의 교차비 (Odds ratio)는 1.04로 독립적인 상관관계를 보이는 것으로 나타났다 $(P=0.019)$.

그 밖에 나이, 성별(남성), 수축기 혈압 등이 관상동맥 석회화에 유 의하게 영향을 주는 인자로 나타났다(OR 1.11, 2.53, 1.02; $P<0.001$, $P<0.001, P=0.007$ ) (Table 4).

\section{고 찰}

본 연구의 목적은 건강한 성인에서 CAC와 허리둘레-신장비의 연 관성을 알아보고자 한 것이다. CAC에 영향을 미칠 수 있는 연령, 성 별, 혈압, 혈중지질 등 여러 인자들을 보정했을 때 허리둘레-신장비가 증가할수록 $\mathrm{CAC}$ 의 위험도가 증가하였고, 이는 허리둘레-신장비가 관상동맥질환의 예측에 유용한 지표가 될 수 있음을 시사한다.

The world health organization (WHO) 기준에 의해 비만 지표로 가장 널리 사용되고 있는 체질량지수는 체지방량을 정확히 반영하지 못할 뿐 아니라, 지방의 분포, 즉 복부 비만의 정도를 가늠할 수 없다 는 한계점이 있다.16-18

허리둘레는 복부지방과 대사증후군의 위험인자를 평가하기 위한 단순하고 정확한 지표로 여겨지며, 임상적으로도 널리 이용되고 있 다. 그러나 성별과 인종에 따라 허리 둘레의 기준치가 다르고, 같은 아 시아 인종 사이에서도 일본에서는 적정 허리둘레의 기준치를 남녀 각각 $85 \mathrm{~cm}, 90 \mathrm{~cm}$ 로 보는 반면, 국내에서는 $90 \mathrm{~cm}, 85 \mathrm{~cm}$ 로 보고 있 는 등 국가에 따른 차이도 존재해 일괄하여 사용하기 어렵다는 단점 이 있다.13,19-22 또한 허리둘레는 신장을 전혀 반영하지 못하기 때문에, 허리둘레만을 비만지표로 사용했을 경우 신장이 큰 군에는 질병 발 생 위험도를 과대평가할 수 있고, 신장이 작은 군에는 위험도를 과소 평가할 수 있다는 연구결과도 있었다. ${ }^{23,24}$

반면, 허리둘레-신장비는 성별이나 인종에 따른 기준치의 차이가 없어, 국내뿐 아니라 영국, 일본, 대만의 연구들에서 허리-신장비의 기 준치를 동일하게 남녀 0.5 로 제시하였다. ${ }^{10,25-27}$ 또한 여러 선행 연구들 에서 심혈관계질환을 예견하는 비만지표로서 허리둘레-신장비의 유
Table 4. Multiple logistic regression analysis between each metabolic parameters and presence of CAC

\begin{tabular}{lccr}
\hline & OR & $95 \% \mathrm{Cl}$ & $P$ value \\
\hline WHtR $(\times 100)$ & 1.04 & $1.01-1.07$ & 0.019 \\
Age $(\mathrm{yr})$ & 1.11 & $1.09-1.13$ & $<0.001$ \\
Male & 2.53 & $1.53-4.19$ & $<0.001$ \\
$\mathrm{SBP}(\mathrm{mmHg})$ & 1.02 & $1.01-1.04$ & 0.007 \\
$\mathrm{DBP}(\mathrm{mmHg})$ & 0.98 & $0.96-1.00$ & 0.052 \\
FPG $(\mathrm{mg} / \mathrm{dL})$ & 1.01 & $1.00-1.01$ & 0.072 \\
TC $(\mathrm{mg} / \mathrm{dL})$ & 1.00 & $0.99-1.01$ & 0.455 \\
Triglyceride $(\mathrm{mg} / \mathrm{dL})$ & 1.00 & $1.00-1.00$ & 0.467 \\
LDL-C $(\mathrm{mg} / \mathrm{dL})$ & 1.01 & $1.00-1.02$ & 0.372 \\
HDL-C $(\mathrm{mg} / \mathrm{dL})$ & 1.02 & $0.90-2.33$ & 0.112 \\
Ex-smoker & 1.08 & $0.67-1.74$ & 0.743 \\
Current smoker & 1.35 & $0.83-2.19$ & 0.225 \\
\hline
\end{tabular}

Data are Mean \pm SD.

$\mathrm{OR}$, odd ratio; $\mathrm{Cl}$, confident interval; $\mathrm{CAC}$, coronary artery calcification; WC, waist circumference; WHtR, waist circumference-to-height ratio; BMl, body mass index; SBP, systolic blood pressure; DBP, diastolic blood pressure; FPG, fasting plasma glucose; TC, total cholesterol; LDL-C, low-density lipoprotein cholesterol.

용성을 입증하였다. Ashwell 등 28 은 허리둘레-신장비가 체질량지수 와 허리둘레에 비해 심혈관계 및 대사질환 위험요인들의 발견에 있어 우월한 지표라 하였고, Savva 등29은 무증상의 성인을 대상으로 한 메 타분석을 통해 허리둘레-신장비가 체질량지수 보다 당뇨, 대사증후 군, 심혈관계질환과 더 밀접한 연관성이 있음을 보여 주었다.

체질량지수에 비해 체지방의 비율이 높고, 평균 신장이 작은 아시 아인의 특성상 허리둘레-신장비와 다양한 심혈관계 위험인자 및 대 사증후군과의 연관성 연구는 특히 아시아에서 많이 이루어졌다. 일 본인을 대상으로 한 Hsieh 등 26 의 연구에서는 허리둘레-신장비가 다 른 비만지표들에 비해 정상 및 과체중인 사람들에서 대사적 질환에 대한 위험을 선별하기에 유용한 지표라고 하였다. 또 최근 대만의 한 단면연구에 의하면 체질량지수나 허리둘레보다 허리둘레-신장비가 당뇨, 고혈압, 고콜레스테롤, 고중성지방 및 저HDL-콜레스테롤의 예 견에 우월한 것으로 나타났으며, 여성의 경우에는 대사증후군을 예 견하는 가장 좋은 지표인 것으로 나타났다. ${ }^{27}$ 국내 연구에서도 Kim 등이 당뇨병 전단계 환자를 대상으로 한 연구에서 허리둘레-신장비 가 다른 비만 지표에 비해 대사증후군을 더 잘 예측한다고 보고했고, Park 등 ${ }^{10}$ 은 허리둘레-신장비가 당뇨병과 고혈압을 예견하는 데 있어 허리둘레 또는 체질량지수 보다 나은 지표라고 하였다.

이렇듯 여러 연구를 통해 허리둘레-신장비와 다양한 심혈관질환 위 험인자 및 대사증후군과의 연관성이 밝혀진 바 있으나 아직까지 직접 적으로 관상동맥석회화 수치와의 연관성을 연구한 논문은 부족하다. 관상동맥석회화 수치(CACS)는 관상동맥협착을 예측하는 지표로 서, CACS와 복부 비만의 연관성에 대한 연구는 많이 이루어져 있으 나 허리둘레-신장비를 복부 비만의 지표로 사용한 연구는 현재까지 
많지 않다.12,30 복부 비만이 중등도 이상의 CAC와 관련이 있음을 보 여준 Choi 등릐 국내 연구나, 복부 비만이 CAC의 존재 여부와 유의 한 관계가 있다고 보고한 Ohashi 등 32 의 연구에서는 허리둘레(WC), 내장지방면적(visceral fat area), 피하지방면적(subcutaneous fat area) 등을 복부 비만을 평가하는 지표로 사용했다. 다만 Kramer 등이 전 향적 연구를 통해 $\mathrm{CAC}$ 의 진행이 허리둘레-신장비의 증가와 독립적 인 양의 상관관계가 있음을 보고한 바 있으나, 연구 시작 시의 평균 연 령이 67세 이상인 고령을 대상으로 한 연구라는 제한점이 있었다.

$\mathrm{CAC}$ 의 위험은 남성 및 연령의 증가와 밀접한 관련이 있는 것으로 잘 알려져 있으며, 심혈관 질환 과거력이 없는 남녀를 대상으로 한 과 거의 연구에 의하면 70 세 이상의 남성의 $90 \%$ 이상, 여성의 $67 \%$ 이상 에서 CAC가 존재한다. ${ }^{33,34}$ 본 연구에서도 연령이 증가할수록, 남성일 경우, $\mathrm{CAC}$ 의 위험이 높은 것으로 나타나 기존의 연구들과 일치하는 결과를 보였다.

수축기 혈압의 증가와 이완기 혈압의 감소로 인한 맥압의 증가가 $\mathrm{CAC}$ 의 증가와 양의 상관관계가 있는데, 이는 혈관 경직도가 증가하 는 50세 이상에서 더 뚜렷하게 나타난다. ${ }^{35-37}$ 본 연구에서도 수축기 혈압이 증가할수록 $\mathrm{CAC}$ 의 위험도가 증가하였다.

중성지방 및 $\mathrm{LDL}$-콜레스테롤의 증가, $\mathrm{HDL}$-콜레스테롤의 감소가 $\mathrm{CAC}$ 증가와 양의 상관관계가 있다고 보고한 이전의 연구들과 달리 본 연구에서는 유의한 상관 관계가 없는 것으로 나타났다. ${ }^{38,39}$ 이는 본 연구가 심혈관계질환의 과거력이 없는 비교적 건강한 성인을 대상 으로 분석한 결과이기 때문일 가능성이 있으며, 식이습관의 차이 또 는 인종의 영향도 배제할 수 없다.

흡연은 중요한 관상동맥질환 위험인자로서, 관상동맥질환의 과거 력이 있는 일본인을 대상으로 한 최근의 연구에서 흡연자의 경우 비 흡연자보다 CAC 및 관상동맥질환의 유병률이 유의하게 높은 것으로 나타났다. ${ }^{40}$ 반면 남성을 대상으로 흡연 상태와 CAC에 연관성을 연 구한 한 국내 연구에서는 대사증후군이 없는 경우 흡연과 $\mathrm{CAC}$ 는 관 련이 없었다는 보고도 있었다. ${ }^{41}$ 본 연구에서는 현재 흡연 상태일 경 우 CAC의 위험이 증가하는 경향성은 보여주었으나, 통계적인 유의수 준에 미치지 못하였는데, 이에 대해서는 흡연량(Pack-years), 금연 기 간, 과거력의 유무 등 상세한 흡연력을 포함한 연구 분석이 필요할 것 으로 생각된다.

본 연구의 제한점은 경기도 수원시 소재 일개 대학병원의 수검자 를 대상으로 하였기 때문에 전 인구에 대해 일반화하기 어렵다는 점, 단면 연구로서 허리둘레-신장비와 CAC 의 연관성은 확인 할 수 있었 으나, 인과관계를 확인할 수 없다는 점이다. 그러나 CAC와 허리둘레신장비의 관계에 대한 선행 연구가 부족한 상황에서, 비교적 큰 규모 의 집단을 대상으로 진행된 연구라는 점에서 본 연구의 강점이 있다.

비만 지표 중 허리둘레-신장비는 인종, 성별의 구분 없이 사용할 수
있고, 측정이 간편하며, 심혈관 질환 및 대사질환의 위험을 평가하는 데 유용한 지표이다. 최근까지의 연구들은 주로 메타분석 또는 단면 연구들에 의한 결과로, 향후 대표적인 신체 계측치로 사용되기 위해 서는 대규모 전향 연구를 포함한 많은 연구자료의 축적이 필요할 것 으로 생각된다.

본 연구를 통해 허리둘레-신장비가 증가할수록 관상동맥석회화의 위험이 증가하는 것을 알 수 있었으며, 이는 허리둘레-신장비가 관상 동맥질환을 예견하는 유용한 지표가 될 수 있음을 시사한다.

\section{요 약}

배경: 허리둘레-신장비가 체질량지수보다 관상동맥질환의 위험요인 들과 더 높은 관련성을 보인다는 것이 여러 연구들을 통해 증명되었 다. 그러나 관상동맥질환의 독립적인 위험인자로 알려진 관상동맥석 회화와 허리둘레-신장비의 관련성에 대한 연구는 아직 부족하다. 본 연구에서는 건강한 성인에서 허리둘레-신장비와 관상동맥석회화의 관련성에 대해 알아보고자 하였다.

방법: 경기도 소재 일개 대학병원 건강검진센터에 내원하여 Coronary artery MDCT를 시행한 성인 중 심혈관계질환의 과거력이 없는 1,111 명을 연구 대상으로 하였다.

결과: Coronary artery calcification score (CACS)가 0 인 군과 그 이상 인 군으로 피험자를 나누었을 때, 허리둘레-신장비는 CACS $>0$ 인 군 에서 CACS $=0$ 인 군보다 더 높은 값을 보였다 $(0.535 \pm 0.006$ vs 0.517 $\pm 0.005, P<0.001)$. 관상동맥석회화에 영향을 미치는 다른 위험요인 들을 보정하였을 때, 허리 둘레-신장비는 관상동맥석회화에 대한 독 립적인 예측인자인 것을 알 수 있었다(OR 1.04; 95\% CI, 1.01-1.07; $P=0.019)$. 또한 성별이 남성일 때, 수축기 혈압이 증가할 때 관상동맥 석회화의 위험은 각각 2.53 배, 1.02 로 증가하였다 $(95 \% \mathrm{CI}, 1.53-4.19$, $P<0.001$; 95\% CI, 1.01-1.04, $P=0.007)$.

결론: 건강한 성인을 대상으로 한 본 연구에서, 허리둘레-신장비가 증 가할수록 관상동맥석회화가 발생할 위험이 높아졌다.

중심단어: 허리둘레-신장비, 관상동맥석회화, 관상동맥질환

\section{Conflicts of Interest}

The researcher claims no conflicts of interest.

\section{References}

1. Asia Pacific Cohort Studies Collaboration. The burden of overweight and obesity in the Asia-Pacific region. Obes Rev 2007;8: 
$191-6$.

2. National Cholesterol Education Program (NCEP) expert panel on detection, evaluation, and treatment of high blood cholesterol in adults (Adult Treatment Panel III). Third report of the National Cholesterol Education Program (NCEP) expert panel on detection, evaluation, and treatment of high blood cholesterol in adults (Adult Treatment Panel III) final report. Circulation 2002;106: 3143-421.

3. Kramer CK, von Mühlen D, Gross JL, Barrett-Connor E. A prospective study of abdominal obesity and coronary artery calcium progression in older adults. J Clin Endocrinol Metab 2009;94: 5039-44.

4. Bener A, Yousafzai MT, Darwish S, Al-Hamaq AO, Nasralla EA, Abdul-Ghani M. Obesity index that better predict metabolic syndrome: body mass index, waist circumference, waist hip ratio, or waist height ratio. J Obes 2013;2013:269038.

5. Park YS, Kim JS. Association between waist-to-height ratio and metabolic risk factors in Korean adults with normal body mass index and waist circumference. Tohoku J Exp Med 2012;228:1-8.

6. Shao J, Yu L, Shen X, Li D, Wang K. Waist-to-height ratio, an optimal predictor for obesity and metabolic syndrome in Chinese adults. J Nutr Health Aging 2010;14:782-5.

7. Sabah KM, Chowdhury AW, Khan HI, Hasan AT, Haque S, Ali S, et al. Body mass index and waist/height ratio for prediction of severity of coronary artery disease. BMC Res Notes 2014;7:246.

8. Kim JI, Yu BC, Jeon MJ, Kim JM, Choi JS, Park JY, et al. Correlation of metabolic syndrome with waist circumference and waistto-height ratio. Korean J Obes 2009;18:87-93.

9. Hsieh SD, Yoshinaga H. Abdominal fat distribution and coronary heart disease risk factors in men-waist/height ratio as a simple and useful predictor. Int J Obes Relat Metab Disord 1995;19:585-9.

10. Park SH, Choi SJ, Lee KS, Park HY. Waist circumference and waist-to-height ratio as predictors of cardiovascular disease risk in Korean adults. Circ J 2009;73:1643-50.

11. Rumberger JA, Simons DB, Fitzpatrick LA, Sheedy PF, Schwartz RS. Coronary artery calcium area by electron-beam computed tomography and coronary atherosclerotic plaque area. A histopathologic correlative study. Circulation 1995;92:2157-62.

12. Wong ND, Hsu JC, Detrano RC, Diamond G, Eisenberg H, Gardin JM. Coronary artery calcium evaluation by electron beam computed tomography and its relation to new cardiovascular events. Am J Cardiol 2000;86:495-8.

13. Lee SY, Park HS, Kim DJ, Han JH, Kim SM, Cho GJ, et al. Appropriate waist circumference cutoff points for central obesity in Korean adults. Diabetes Res Clin Pract 2007;75:72-80.

14. Grundy SM, Cleeman JI, Daniels SR, Donato KA, Eckel RH, Franklin BA, et al. Diagnosis and management of the metabolic syndrome: an American Heart Association/National Heart, Lung, and Blood Institute scientific statement: Executive Summary. Crit Pathw Cardiol 2005;4:198-203.

15. Expert panel on detection, evaluation, and treatment of high blood cholesterol in adults. Executive summary of the third report of the National Cholesterol Education Program (NCEP) expert panel on detection, evaluation, and treatment of high blood cholesterol in adults (Adult Treatment Panel III). JAMA 2001;285: 2486-97.

16. Kaplan NM. The deadly quartet. Upper-body obesity, glucose intolerance, hypertriglyceridemia, and hypertension. Arch Intern Med 1989;149:1514-20.

17. Després JP. Lipoprotein metabolism in visceral obesity. Int J Obes 1991;15 Suppl 2:45-52.

18. Blair D, Habicht JP, Sims EA, Sylwester D, Abraham S. Evidence for an increased risk for hypertension with centrally located body fat and the effect of race and sex on this risk. Am J Epidemiol 1984;119:526-40.

19. Pouliot MC, Després JP, Lemieux S, Moorjani S, Bouchard C, Tremblay A, et al. Waist circumference and abdominal sagittal diameter: best simple anthropometric indexes of abdominal visceral adipose tissue accumulation and related cardiovascular risk in men and women. Am J Cardiol 1994;73:460-8.

20. Ledoux M, Lambert J, Reeder BA, Després JP. Correlation between cardiovascular disease risk factors and simple anthropometric measures. Canadian Heart Health Surveys Research Group. CMAJ 1997;157 Suppl 1:S46-53.

21. Lemos-Santos MG, Valente JG, Gonçalves-Silva RM, Sichieri R. Waist circumference and waist-to-hip ratio as predictors of serum concentration of lipids in Brazilian men. Nutrition 2004;20:85762 .

22. Examination Committee of Criteria for 'Obesity Disease' in Japan; Japan Society for the Study of Obesity. New criteria for 'obesity disease' in Japan. Circ J 2002;66:987-92.

23. Browning LM, Hsieh SD, Ashwell M. A systematic review of 
waist-to-height ratio as a screening tool for the prediction of cardiovascular disease and diabetes: 0.5 could be a suitable global boundary value. Nutr Res Rev 2010;23:247-69.

24. Hsieh SD, Yoshinaga H. Do people with similar waist circumference share similar health risks irrespective of height? Tohoku J Exp Med 1999;188:55-60.

25. Ashwell M, Lejeune S, McPherson K. Ratio of waist circumference to height may be better indicator of need for weight management. BMJ 1996;312:377.

26. Hsieh SD, Yoshinaga H, Muto T. Waist-to-height ratio, a simple and practical index for assessing central fat distribution and metabolic risk in Japanese men and women. Int J Obes Relat Metab Disord 2003;27:610-6.

27. Li WC, Chen IC, Chang YC, Loke SS, Wang SH, Hsiao KY. Waistto-height ratio, waist circumference, and body mass index as indices of cardiometabolic risk among 36,642 Taiwanese adults. Eur J Nutr 2013;52:57-65.

28. Ashwell M, Gunn P, Gibson S. Waist-to-height ratio is a better screening tool than waist circumference and BMI for adult cardiometabolic risk factors: systematic review and meta-analysis. Obes Rev 2012;13:275-86.

29. Savva SC, Lamnisos D, Kafatos AG. Predicting cardiometabolic risk: waist-to-height ratio or BMI. A meta-analysis. Diabetes Metab Syndr Obes 2013;6:403-19.

30. Lee TH, So MS, Kim BJ, Kang JG, Sung KC, Kim BS, et al. The association between epicardial fat thickness and coronary artery calcification according to blood pressure status in nonhypertensive individuals: from the CAESAR study. J Clin Lipidol 2015;9:30512.

31. Choi SY, Kim D, Oh BH, Kim M, Park HE, Lee CH, et al. General and abdominal obesity and abdominal visceral fat accumulation associated with coronary artery calcification in Korean men. Atherosclerosis 2010;213:273-8.

32. Ohashi N, Yamamoto H, Horiguchi J, Kitagawa T, Hirai N, Ito K, et al. Visceral fat accumulation as a predictor of coronary artery calcium as assessed by multislice computed tomography in Japa- nese patients. Atherosclerosis 2009;202:192-9.

33. Wong ND, Kouwabunpat D, Vo AN, Detrano RC, Eisenberg H, Goel M, et al. Coronary calcium and atherosclerosis by ultrafast computed tomography in asymptomatic men and women: relation to age and risk factors. Am Heart J 1994;127:422-30.

34. Goel M, Wong ND, Eisenberg H, Hagar J, Kelly K, Tobis JM. Risk factor correlates of coronary calcium as evaluated by ultrafast computed tomography. Am J Cardiol 1992;70:977-80.

35. Franklin SS, Gustin W 4th, Wong ND, Larson MG, Weber MA, Kannel WB, et al. Hemodynamic patterns of age-related changes in blood pressure. The Framingham heart study. Circulation 1997;96:308-15.

36. Bielak LF, Turner ST, Franklin SS, Sheedy PF 2nd, Peyser PA. Age-dependent associations between blood pressure and coronary artery calcification in asymptomatic adults. J Hypertens 2004;22: 719-25.

37. Kim DS, Smith JA, Bielak LF, Wu CY, Sun YV, Sheedy PF 2nd, et al. The relationship between diastolic blood pressure and coronary artery calcification is dependent on single nucleotide polymorphisms on chromosome 9p21.3. BMC Med Genet 2014;15:89.

38. Cao HL, Chen XB, Lu JG, Hou ZH, Tang X, Gao Y, et al. Metabolic syndrome and coronary artery calcification: a communitybased natural population study. Chin Med J (Engl) 2013;126:461823.

39. Orakzai SH, Nasir K, Blaha M, Blumenthal RS, Raggi P. NonHDL cholesterol is strongly associated with coronary artery calcification in asymptomatic individuals. Atherosclerosis 2009;202: 289-95.

40. Yano M, Miura S, Shiga Y, Miyase Y, Suematsu Y, Norimatsu K, et al. Association between smoking habits and severity of coronary stenosis as assessed by coronary computed tomography angiography. Heart Vessels 2016;31:1061-8.

41. Lee YA, Kang SG, Song SW, Rho JS, Kim EK. Association between metabolic syndrome, smoking status and coronary artery calcification. PLoS One 2015;10:e0122430. 